\title{
LENE TEGLHUS
}

\section{FRIDAS GRYDE}

\author{
Moral, modernitet og mad i det vestlige Kenya
}

Som en introduktion til den historie, ${ }^{1}$ jeg her vil fortælle, vil jeg tage læseren på en rejse til det landskab, der er beboet af luo folket i det vestlige Kenya. Vi lander lige ved ækvator, på bredden af Victoriasøen, der, hvor denne Afrikas største sø strækker sig fra Uganda og Tanzania ind i Kenya. Jorden er rød og tør, for det regner ikke meget og kun i regntiden. Det tordner ofte om eftermiddagen, og de stedvise, mørke skyer skaber et fantastisk lys, men giver sjældent regn. Kvinder er klædt i farver, og der er mange børn overalt, som råber mzungu, swahili for fremmede, når man passerer. Luo-familien bor i en samling af huse, dala, med stråtag eller blikplader, organiseret i en orden, der reflekterer det sociale hierarki i den udvidede familie. Luo er patrilineære og patrilokale, og da polygami er udbredt, er en dala ofte beboet af flere medhustruer. Mange børn vil vokse op i udvidede familier, men modernitet influerer billedet både i form af et stigende antal kernefamilier og i form af de mange fraværende mænd, mænd, der er migrantarbejdere eller er døde på grund af aids-epidemien som kræver op imod hvert femte liv her (KDHS 1998, 2004).

Disse aspekter af modernitet og forandring gennemtrænger den verden, vi her skal høre om, ligesom også fattigdom og mangel på mad gør det.

Gruppen af luo udgør den næststørste etniske gruppe i Kenya og hører til de nilotiske folk, der befolker store dele af området omkring Victoriasøen, som for eksempel iteso (Meinert 2001) og jop'adhola (Mogensen 1999). Luo taler dholuo, et nilotisk sprog. Man lever af agerbrug og/eller fiskeri, nogle fă holder husdyr, og migrantarbejde, at mænd tager til byen for at arbejde, er et væsentligt aspekt af den rurale økonomi. De fleste luo er kristne med tilhørsforhold til enten den protestantiske eller den katolske kirke. Men også andre forestillinger om det gode og det onde end de kristne præger tilværelsen her; manglende overholdelse af traditionerne kan skabe en negativ kraft, der påvirker ikke bare den enkelte, men samfundet som helhed.

Med denne korte introduktion til livet i det vestlige Kenya, til den vibrerende varme og støvet i luften vil jeg nu præsentere hovedpersonen i min udlægning af dette landskab, Frida. Hovedparten af det empiriske materiale i denne sammenhæng er mine samtaler med Frida og min deltagelse $\mathrm{i}$ især et bestemt møde $\mathrm{i}$ hendes enkegruppe. Der vil dog være referencer til både andre enkeltindivider og til grupper af henholdsvis enker og kvinder generelt. 


\section{Frida, min lily}

Frida er en 27-årig enke, mor til to levende børn på fem og tre år. Hun bor med sine børn i et lejet hus på stranden ved Victoriasøen i det vestlige Kenya. Frida har valgt at gå imod traditionen, som kræver, at hun indgår i et levirat-ægteskab, dvs. at hun skal indgå ægteskab med en bror til den afdøde mand eller en anden, som den patrilineale familie udpeger. Leviren skal have sex med hende for at ophæve tilstanden af urenhed, som i henhold til traditionen opstår i forbindelse med ægtefællens død, chodo kola. Hun fortæller at hun faldt i unåde i sin afdøde mands familie på grund af sin beslutning og blev sendt ud af dalaen, hvor hun var flyttet ind, da hun blev gift med sin nu afdøde mand. Hun blev med andre ord ekskluderet fra slægtskabet og frataget sin status som svigerinde og svigerdatter i den patrilineale slægt, fordi hun ikke ville sørge for ophævelsen af chodo kola på den måde, som traditionen pålægger hende det. Historien om Frida handler om eksklusion og inklusion og vil folde sig ud over de tre temaer moral, modernitet og mad. Disse temaer afspejler hver især vigtige aspekter af det levede liv $i$ en landsby $i$ det vestlige Kenya i dag, de udgør tilsammen indholdet af „Fridas gryde“. Fridas situation er præget af aktivering og forhandling af slægtskabsrelationer, moral og forpligtelser i en verden præget af ikke alene manglen på mad, men også af aspekter af modernitet, især aids. Hendes historie viser den kompleksitet, der præger slægtskabsrelationer såvel som andre relationer i relation til forpligtelser og fordømmelser, inklusioner og eksklusioner.

Jeg vil i det følgende omtale Fridas afdøde mands familie som Fridas familie, da dette er i overensstemmelse med den lokale praksis. Når jeg omtaler Fridas biologiske ophav, vil jeg eksplicitere dette.

Fridas situation åbner for en diskussion af slægtskab og forbundethed $i$ en verden af uvished. Jeg vil se på Fridas status som kvinde, mor og enke i lyset af en debat af slægtskabsanalyse og nyere teori om forbundethed (Carsten 2004, 2000). Ligesom det på Evans-Pritchards tid var slægtskabsstrukturer, der var temaet, så er vi i dag i antropologien temmelig ukritisk i gang med at give aktørperspektivet samme status. I relation til forbundethed er konsekvensen, at fokus er på inklusion i langt højere grad end på eksklusion (se Prince 2004 for et lignende argument).

Fridas situation er, som andre enkers, præget af uvished. Fattigdom, sult, sygdom og social lidelse er en del af det hverdagsliv, som kvinder i dette område lever. Frida forhandler sin position både i familien og i samfundet og kæmper for sine børn og sig selv i denne verden af uvished. For at forstå, hvad der er på spil, når Frida taler om og handler i forhold til familien og det sociale netværk i øvrigt, vil jeg argumentere for, at både traditionel slægtskabsanalyse og nyere teorier om forbundethed har relevans for forståelsen af det levede liv i Fridas verden. På denne måde vil jeg tegne et nuanceret billede af, hvad det vil sige at være kvinde i det vestlige Kenya. Jeg vil demonstrere, hvordan mad, moral og modernitet er aspekter af slægtskab og forbundethed for enker og for andre, unge og ældre kvinder, børn og mænd i et ruralt område i det vestlige Kenya.

Frida var en udfordrende informant, fordi hun ofte løj eller undlod at svare. Udfordringen bestod $i$ at finde ud af hvorfor - selv om jeg ofte følte, at jeg ikke kunne bruge hende som informant, når jeg ikke kunne stole på hende. Men kan vi nogensinde stole på vore informanter? Det er en diskussion, der falder uden for rammerne her, jeg 
vil blot pointere, at puslespillet med at finde mening i Fridas udtalelser, tavsheder og løgne var lærerigt og gav mig indsigt $\mathrm{i}$ især det moralske univers på en helt særlig måde. ${ }^{2}$

\section{Slægtskab - struktur og aktør}

Slægtskabsstudier i Østafrika har allerede tidligt i antropologiens historie kortlagt, hvordan luo og andre nilotiske grupper har organiseret deres samfund omkring slægtog klanstrukturer. Evans-Pritchard fastslår i en artikel fra 1949, at luo-samfundets organisation ligner nuernes, som han har beskrevet så indgående $(1949,1950)$. Som nuerne fremstod luo som et klassisk patrilineært, segmentært samfund med slægtskab som reproduktionen af faste mønstre af nedstamning over tid. Evans-Pritchard antager, at slægtskabsrelationer ganske simpelt er udtryk for slægtskabssystemer. Hans strukturfunktionalistiske tilgang sætter den politiske organisation i fokus, og selv om han demonstrerer, hvordan lokale værdier og etik giver mening for lokale mennesker, så er hans fokus ikke på levede relationer, ej heller på kvinder som andet end hustruer. Men hans analyse af afstamning og slægtskabsforbindelser er alligevel relevante for vores forståelse af, hvad der er på spil. Luo-folk bliver til i andres øjne ved at definere, hvis søn, datter eller hustru de er, hvilken slægt de tilhører, og hvilken klan deres slægt er en del af. Cohen og Odhiambo (1989) beskriver, hvordan der, når man møder en fremmed, er en nærmest ritualiseret tilkendegivelse af tilhørsforhold. De argumenterer for, at man på denne måde definerer sig selv. Kvinder i luo-land flytter ved ægteskabets indgåelse ind i mandens dala, og ægtemanden billiger ikke, at hustruen besøger sin biologiske familie særlig ofte; de fleste mænd mener, at en, højst to gange årligt er tilstrækkeligt. Tilhørsforhold er vigtige, og det kan være forvirrende for en kvinde, mener en af mine mandlige informanter, hvis hun ikke er helt og fuldt i sin (nye) familie. Mødre definerer sig også som mor til ... (uanset køn) - min Lily (= mor til Lily) i Fridas tilfælde. Dette afspejler ligeledes relationers betydning for, hvem man er. Jeg blev for eksempel til min Sebastian, fordi min førstefødte hedder Sebastian - og det på trods af at han kun var til stede på billeder, jeg havde medbragt.

Pointen er, at slægtskabssystemer, akkurat så rigide, som de synes beskrevet af Evans Pritchard, leves i kvindernes hverdag og definerer deres status og plads i samfundet. Jeg vil uddybe dette i det videre forløb i fortællingen om Frida. Forståelsen af slægtskabssystemerne er overordentlig vigtig for at begribe en luo-enkes opfattelse af retten til at bestemme over sin egen krop og over, hvem hun er. En enkes relation til den patrilineære familie hører ikke op, selv om ægtefællen er død. Hvis hun for eksempel føder et barn som resultat af levirat-ægteskabet, tilhører barnet den afdøde ægtefælles slægt. Hendes relation til familien er efter mandens død defineret ved hendes rolle som mor til hans børn, og denne relation synes i langt de fleste tilfælde at afføde de samme rettigheder og forpligtelser, som var gældende, før ægtefællen døde.

Evans-Pritchards analytiske perspektiv lader dog kvindernes agens helt ude af syne; de indgår ægteskaber og knytter bånd mellem klaner, men fokus er på systemet og mænd, ikke kvinder, som aktører. Vi skal frem til den feministisk inspirerede antropologi for at indkredse kvinders agens i slægtskabssystemet. Christine Obbo (1980) har arbejdet med et mere domesticeret perspektiv end Evans Pritchard og har beskrevet, hvordan 
kvinders position i samfundet ændrer sig i takt med betingelserne. Positioner forhandles og forandres, og kvinderne har indflydelse på dette, selv om kønshierarkiet undertrykker dem. I lighed med Obbo, som har beskrevet det for ganda-kvinderne i Uganda, finder også luo-kvinderne innovative måder at håndtere deres position på. Også Cohen og Odhiambo (1989) beskriver, hvordan fattigdommen og mangel på mad får luo-kvinder til at arbejde uden for hjemmet og derved udfordre kønshierarkiet, som er et element af samfundets struktur.

I nyere studier, som for eksempel Ruth Prince (2004), får slægtskab karakter af at være en ,aktør", eller i hvert fald et aktiv, snarere end en struktur i Evans-Pritchard'sk forstand. Prince diskuterer nyere litteratur om forbundethed, der bygger på præmissen om, at slægtskab er et normativt træk, som folk forholder sig aktivt til, i relation til andre kulturelle værdier og praktiske dilemmaer. Hun peger på, at svagheden ved disse nye teoretiske tiltag er et ensidigt fokus på inklusion, som overser eksklusion. Ved at se slægtskab som en proces bliver systemet til et flydende og flertydigt aspekt, der ikke alene kan fungere som en struktur, men også kan tolkes, forhandles og bruges som et aktiv. I relation til historien om Frida er denne tilgang vigtig. Men for at forstå, hvordan slægtskab er flydende og flertydigt og rummer mulighed for både inklusion og eksklusion, er det en forudsætning at begribe strukturen som en mere essentialiseret størrelse. For det er som sådan, den optæder i luo-kvinder og -mænds bevidsthed, hvad enten det skal ses som et udtryk for en „re-traditionalisering“, en tendens, som både Prince (2004) og Cohen og Odhiambo (1992) beskriver, eller som et vedvarende essentielt aspekt af en kollektiv luo-bevidsthed.

Men lad os nu vende tilbage til Frida for at uddybe hendes position i familien og i samfundet for at se nærmere på, hvordan rigide slægtskabsstrukturer og andre traditioner udgør en strukturel ramme for Fridas handlingsrum, samtidig med at de er et ,aktiv“ i hendes forhandling af sin position i relation til in- og eksklusion.

\section{Kwer og chira- udtryk for en moralsk diskurs}

Konsekvensen af Fridas beslutning er, at der opstår chira. Chira er lidelser forårsaget af brud på traditioner, kwer. Kwer er svær at afgrænse, mange forskellige handlinger kan defineres som kwer, ligesom der er et situationelt aspekt omkring kwer, men at afvise levirat er altid kwer.

Kwer og chira spiller en kolossal rolle for luo. Enhver lidelse kan tilsyneladende tilskrives brud på traditioner (kwer) - og bliver det ofte. Hvis et barn bliver sygt eller dør, vil man oftest tale om chira, uagtet at en mere ,moderne“ medicinsk diagnose er stillet. Man vil, ofte sideløbende med „moderne“ medicin, behandle syge både børn og voksne med manyasi, urtemedicin. Den ,vestlige“ medicinske behandling udelukker ikke den ,traditionelle, lokale ${ }^{\text {‘3 }}$ urtemedicin, for chira går, som også hekseri, mere på årsagen til, at sygdommen ramte, end på sygdommens medicinske ætiologi. De omstændigheder, der karakteriserer situationen, rummer for luo svaret på spørgsmålet: Hvorfor netop dét barn? Hvorfor netop dén familie?

På den måde er chira ofte en etikette, der påhæftes en begivenhed, efter at begivenheden har fundet sted. Lad mig illustrere. Hvis et barn er sygt, vil moderen, hvis hun har råd, tage barnet til klinikken, hvor hun sandsynligvis vil få antibiotika. Tilbage i 
hjemmet vil andre kvinder, svigermor, svigerinder eller naboer, vise deres deltagelse $\mathrm{i}$ hendes situation ved at råde hende til at behandle barnet med manyasi. Prince (2004) har beskrevet, hvordan manyasi er et vigtigt aspekt af relationer mellem kvinder i det vestlige Kenya. Hun argumenterer for, at udvekslingen af manyasi er et element af forbundethed, helt i tråd med den måde som jeg i denne sammenhæng vil diskutere mad som et element, eller en substans, af forbundethed. Men først vil jeg uddybe min redegørelse for kwer og chira.

Frida valgte altså traditionen fra og udsatte derved sin familie for risikoen for chira. Hendes afdøde mands brødre lejede et hus på stranden og bad Frida og hendes børn flytte ud af dalaen. Mange af kvinderne i mit studie bor alene med deres børn, nogle på grund af migrationsarbejde, som er udbredt blandt luo-mænd, andre på grund af enkestand. Flere af dem har valgt levirat-ægteskabet fra. Nogle flytter "frivilligt“ fra deres patrilineale familie, mens andre bliver boende i den. Det kan synes oplagt at flytte tilbage til sin biologiske familie, når ens umiddelbare tilknytning til mandens familie hører op, men som en af enkerne i mit studie forklarede, så ville hendes far være bekymret, hvis hun blev mere end et par dage, for som hun sagde: „Hvis jeg kommer for ofte og bliver for længe er de bange for at jeg flytter hjem, og det er kwer, så min far vil smide mig ud efter et par dages besøg" (Anita, 40 år, enke).

Kwer og chira er aspekter af det levede liv, som kan karakteriseres som moralsk signifikante. De udgør rammen for det moralske landskab, som kvinder og mænd i luoland orienterer sig i. Det moralske landskab er et landskab, som kvinderne kun er delvis opmærksomme på. Det tager form af deres handlinger, samtidig med at det er en form, hvori deres handlinger finder sted. Handlinger i relation til kwer og chira inden for det moralske landskab binder disse enkers skæbne sammen, samtidig med at hver enkelt af dem forhandler sin situation og overskrider de normer af rationalitet og irrationalitet, som ligger i det moralske landskab. Intersubjektivitet er et vigtigt aspekt af dette moralske landskab. Forhandlingen af rationalitet og irrationalitet, af rettigheder og forpligtelser finder sted, mens kvinderne lever deres liv som en del af det luo-landskab, som de selv betegner med et ord, der også betyder eksistens. Som Cohen og Odhiambo har sagt det:

For en person fra Siaya betyder „landskab“ ikke blot det fysiske terræn. Ordet konstituerer snarere muligheder og begrænsninger i det rum, som omfatter både det fysiske landskab, menneskene $\mathrm{i}$ det og den kultur, igennem hvilken folk handler og behandler de muligheder, landskabet giver dem. Landskab betyder „eksistens“ (1989:9, min oversættelse).

For at nærme os en forståelse af det moralske handlerum, som en enke har, vil vi se lidt nærmere på Fridas situation, nemlig hendes chodo kola-status.

\section{Chodo kola}

Chodo kola er den lokale betegnelse for den tilstand af urenhed, som en enke er i umiddelbart efter sin mands død, og som ophæves ved et rituelt samleje. Kvinderne i mit studie fortæller, at levirat-traditionen har ændret sig gennem tiden. Oprindeligt var den en social sikkerhedsanordning, der skulle sikre en enke i den første tid efter tabet af den afdøde mand. Det var den paternale families ansvar at finde en levir, som 
så påtog sig ansvaret for at ophæve chodo kola. Dette kunne foregå på forskellig vis, og Cohen og Odhiambo (1989) beskriver, at det mindste engagement var at hænge sin jakke og ryge en cigaret i enkens bolig. Denne udvej syntes dog ikke mulig blandt de kvinder, jeg har talt med. De angiver, at ældre kvinder, hvis børn var voksne, kunne slippe af sted med en sådan løsning, men ikke yngre kvinder. Ifølge Cohen og Odhiambo (ibid.) ville leviren i et vist omfang overtage den afdødes sociale og økonomiske ansvar. Fænomenet er også beskrevet hos fulani:

Den afdøde mands bror, eller en patrilineal fætter, som regel en ung mand, skal optræde som en beskytter af den døde mands børn, og han skal medvirke ved indgåelsen af deres ægteskabsaftaler. Han skal arve mindst en af den afdøde mands enker, især hvis hun er i den fødedygtige alder (Stenning 1971:117, min oversættelse)

Man ville, specielt tidligere, også blandt luo ofte vælge en yngre bror til afdøde som levir, og selv om det er beskrevet, hvordan enken får endnu en mund at mætte på denne måde (Potash 1986), så er det flere af mine informanters opfattelse, at leviren generelt var en støtte før i tiden. I dag synes levirens opgave en anden; der er fokus på den rituelle renselse, og aspektet af social sikkerhed synes udvandet, mændene er nu i langt højere grad en belastning. ${ }^{4}$ På den måde er chodo kola blevet et moralsk mere end et socialt anliggende.

Huset på stranden er en materialisering af Fridas position i familien. Flytningen er en eksklusion fra det fælleskab, som skulle være hendes sociale sikkerhedsnet. Hendes valg i forhold til levirat er kwer, brud på traditionen, hvilket antages at ville forårsage chira. Dette faktum påvirker Fridas status i familien og i samfundet. Hun er potentielt under anklage, så at sige, hver gang en ulykke rammer. Fridas beslutning kan tolkes som uansvarlig i kwer/chira-perspektivet, og historier om store eller voksne børn, der pryglede deres mor, hvis hun havde valgt levirat-ægteskabet og dermed den rituelle renselse fra, var udbredte.

Som Obbo (1980) og Ringsted (2000) også påpeger, er enker i en sårbar situation. Kvinden er underordnet inden for slægtskabs- og ægteskabsinstitutionen, og som enke er hun uren, indtil den rituelle renselse er udført, med andre ord indtil hun er blevet „overtaget" af leviren, indtil hun har gennemført et samleje med ham. I lyset af hiv/aids er denne tradition et livsfarligt spil. I modsætning til tidligere findes leviren i dag ofte uden for den afdøde ægtemands familie. Der findes „professionelle“ levirer, som rejser fra enke til enke, mænd, der har valgt dette som deres levevej. Mange kvinder byder leviren velkommen, uanset om han er en del af den patrilineære familie eller en udefrakommende, for de finder, at der ikke er anden vej end den rituelle renselse. En levir flytter ind og er i langt de fleste tilfælde en mund, der skal mættes for en tid. Hvis enken bliver gravid, flytter leviren videre, hvilket i de fleste tilfælde er det, der afslutter relationen. Børn af leviren er den afdøde mands børn, ikke levirens, og det er kwer for leviren at blive, når enken skal føde sin afdøde mands barn. Der er dog eksempler på, at en enke og leviren gifter sig „rigtigt“, når den rituelle relation har varet en passende tid.

Selv om overvejelser omkring hiv/aids ikke eksplicit kom til udtryk i interviews med Frida, så er det en generel opfattelse blandt de af enkerne i mit studie, som indvilligede $i$ at tale om problematikken, at levirer ofte er „dårlige mænd“, mænd, der udnytter dem mere, end de tager del i ansvaret for husholdet. Fridas præcise grunde til 
at vælge, som hun gjorde, er ikke noget, hun havde lyst til at dele med mig; direkte adspurgt trak hun blot på skuldrene. Min assistent og andre i mit studie har valgt leviren fra, fordi de er bange for aids. Enkelte har endda en negativ test og vil derfor ikke udsætte sig for fare, for deres børns skyld. Omkostningerne ved at vælge leviratægteskabet fra, er betydelige for Frida. Derfor må man antage, at hun har væsentlige grunde, selv om hun ikke ønsker at indvi antropologen i dem.

Det forekommer ofte, at især yngre enker flytter ud af dalaen efter ægtemandens død. I nogle tilfælde angiver enken, at det var hendes eget valg, mens Frida altså hævder, at hun er blevet opfordret til at flytte, ved at hendes svogre har lejet huset. Flytningen kan dog i begge tilfælde ses som et led i en forhandling om retten til at bestemme over sin egen krop, som en kontrovers over moralske aspekter. Flere af enkerne i mit studie hævder, at de vier deres liv til Jesus, og at kirken er deres „levir“, hvilket tidligere har været en accepteret handlemåde, især for ældre kvinder. Det betyder, at de afstår fra seksuelle relationer og lever i cølibat. Måske fordi antallet af unge enker er stigende, måske fordi enker nu oftere vælger levirat fra, har holdningen til denne strategi ændret sig. Flere informanter beskrev, hvordan denne undvigelse nu er til debat. En enkelt beskrev, hvorledes hun konkret var blevet truet med voldtægt af sine slægtninge, hvis hun fastholdt sin modstand mod levirat, selv om hun hævdede at være ,gift med Jesus“. Mange, både mænd og kvinder, hævder, at grunden til, at så mange dør unge i dag, er, at kvinderne bryder traditionen og forårsager chira.

Jeg vil uddybe den moralske kontrovers ved at beskrive et møde i den enkegruppe, i hvilken Frida er medlem. Jeg vil dog først introducere fænomenet kvindegrupper i almindelighed for at demonstrere, hvordan disse grupper er sociale rum for debat og forandring.

\section{Modernitet udtrykt gennem kvindegrupper}

Ud over aids og migrationsarbejde er kvindegrupper et aspekt, som jeg definerer som modernitet.

Det fremgår af den kenyanske regerings „Policy Guidelines“ fra 1996, at kvindegrupper indgår som et vigtigt led i kvinders ligestilling på det politiske niveau. Kvindegrupper er et udbredt fænomen over hele landet og må ses som et udtryk for modernitet, selv om Ahlberg (1991 i Ringsted 2000) påpeger, at den slags grupperinger også var almindelige $\mathrm{i}$ både det prækoloniale og det koloniale Kenya. Gruppernes aktiviteter kan generelt karakteriseres som græsrodsarbejde, og selv om de ikke formelt er tilknyttet større kvindeorganisationer, er lokale grupper ofte inspireret af kvinder, som gennem deres organisering i disse optræder på magtens arena.

Kvindegrupper i det vestlige Kenya genererer en form for hjælp til selvhjælp i økonomisk henseende. Som sociale relationer har kvindegrupperne en konkret betydning i forhold til den økonomiske situation, kvinderne befinder sig i, men også på et mere abstrakt niveau udveksles der en slags moralsk anerkendelse i grupperne. Kvindegrupperne er fællesskaber, som konstituerer sig gennem medierende relationer; kvinderne knyttes sammen ikke blot gennem de materielle fordele, de kan opnå i gruppen, men også ved at dele de opfattelser af værdier og moral, som knytter sig til fællesskabet i gruppen. 
Kvindegrupper har en historisk betydning, der er interessant i relation til forandringsprocesser og modernitet. I 1970'erne blev kvindegrupperne institutionaliserede som et led i lokalpolitisk respons på det øgede globale fokus på kvinders rettigheder (Were 1991). Tidligere var ældre kvinder sædvanligvis mest engagerede i grupperne, mens yngre kvinder havde for meget arbejde i hjemmet til at kunne deltage regelmæssigt (Achola 1991). Dette har dog tilsyneladende ændret sig; både unge og ældre kvinder i mit studie deltog i grupper. Institutionaliseringen betyder, at grupper er registreret og har et certifikat, men ellers knytter der sig ikke noget konkret til registreringen. Nogle grupper er stærkere institutionaliserede end andre ved for eksempel at have mødereferat, og ved at forskellige gruppemedlemmer har forskellige ansvarsområder. Nogle grupper udspringer af slægtskabsbaserede fællesskaber, andre af lokale nabofællesskaber, mens andre igen er knyttet til en bestemt status såsom enkestand, eller at man tilhører et specifikt religiøst fællesskab.

Grupperne er sociale relationer eller netværk, som har en konkret betydning i forhold til den økonomiske situation, kvinderne befinder sig i. Som nævnt genererer kvindegrupperne en form for hjælp til selvhjælp $\mathrm{i}$ økonomisk henseende. Grupperne er baserede på „,money-go-round“, hvilket betyder, at alle gruppens medlemmer giver et beløb til værtinden, som er en funktion, der går på skift. Det er ofte grupper af meget initiativrige kvinder, nogle med lidt uddannelse, andre uden, nogle med virkelig svære livsvilkår, andre med lidt flere ressourcer. De deler en forestilling om, at hvis de holder sammen, så kan de gøre en forskel.

Det fremhæves ofte i grupperne, hvordan økonomiske aspekter er et helt grundlæggende træk ved forståelsen af gruppens forbundethed. Ud over denne pengeudveksling er grupperne i varierende grad interesserede i udvikling, både af kvindernes muligheder for at skabe sig en indtægt, men også i udvikling på samfundsniveau. En gruppe har støttet et medlem i at etablere en restaurant, ved at hun har lånt penge til udstyret, de har etableret et dagligt marked, hvor flere af kvinderne sælger deres egne eller andres landbrugsprodukter, nogle sælger fisk, og andre igen sælger brugt tøj. For nylig har en gruppe etableret en landsbybank. Ideen er, at banken skal kunne låne penge ud og på den måde generere indtægt til gruppen, penge, de vil bruge til sociale formål.

Nogle grupper er mere åbne end andre. En af de grupper, jeg lærte at kende, var meget kritisk over for nye medlemmer. Hvis et potentielt medlem søgte optagelse, ville man forsøge at danne sig et indtryk af, hvilken ,slags“ person der var tale om, og på den baggrund ville gruppen på demokratisk vis afgøre, hvorvidt ansøgeren kunne optages i gruppens fællesskab. Man ønskede kun medlemmer med „den rette holdning“, dvs. personer, der delte gruppens opfattelse af moral og etik samt deres forestilling om fællesskabets betydning. Denne procedure er speciel for netop denne gruppe, de fleste grupper er mere åbne. Deltagelse kræver dog i langt de fleste tilfælde, at medlemmet kan betale til pengeudveksling, hvilket i nogle grupper er et relativt stort beløb.

De indtægter, gruppen genererer, går ikke nødvendigvis kun til vækst for medlemmerne i gruppen. Som nævnt er nogle grupper også optaget af forskellige opgaver af social karakter. En gruppe søger for eksempel eksterne midler fra ngo'er til finansiering af deres støtte til forældreløse børn.

Den samme gruppe er ydermere optaget af at formidle viden om sundhed; flere af gruppens medlemmer har, af og til med gruppens økonomiske støtte, taget uddannelse som „,community health worker“, lokal sundhedsarbejder, og de forsøger at dele deres 
viden med andre kvinder, først og fremmest ved at foregå som gode eksempler på velinformerede og ansvarlige mødre og hustruer. De lægger megen vægt på, at de ikke „prædiker sundhed“, men i stedet viser, hvad der virker, og derved inspirerer deres medsøstre (for uddybning, se Teglhus 2005).

Vi ser altså, at gruppen ikke alene styrker sociale forbindelser og følelsen af solidaritet internt ved at bruge penge som en substantive vector (Hutchinson 2000), en konkret substans, der skaber forbundethed gennem udvekslingen af den, men også at gruppen definerer moralske aspekter af det at være kvinde og mor. Ansvarlighed i forhold til blandt andet forældreløse børn, $i$ forhold til pleje af aids-syge og i forhold til sundhedsfremmende adfærd i det hele taget ligger gruppen meget på sinde, og de er bevidste om, hvilken indflydelse deres arbejde har i samfundet, både på det økonomiske og det moralske område.

I forhold til kønshierarki er gruppernes økonomi interessant på den måde, at pengene, ligesom maden i familien, som jeg vil komme ind på nedenfor, er kvindernes domæne. Gruppernes økonomi er et fælles anliggende, og ingen ægtemand kan få adgang til de fælles midler. På den måde er kvindegrupperne en økonomisk ressource, som de helt uden for mandens rækkevidde disponerer over sammen med de øvrige medlemmer af gruppen. Forholdet mellem mænd og kvinder er præget af kvindeundertrykkelse på mange måder, men her har kvinderne altså „helle“. Pengene i gruppen er derfor en særlig slags penge, til hvilke der er knyttet særlige værdier. Disse værdier er forbundet med udvikling, som kvinderne selv definerer det, udvikling af produktion og marked og af omsorg og sundhed. Man kan sige, at der er tale om en udvikling, der er baseret på særlige værdier, som udspringer af den i gruppen forhandlede moral og etik. Det er de problemer, som kvinderne finder mest presserende, de handler på, og deres ideer om løsninger er præget af deres moralske horisonter.

\section{Fridas enkegruppe}

Frida var som nævnt med i en enkegruppe, i hvilken også en af mine assistenter var med. Flere af de yngre enker i gruppen havde valgt leviratet fra, mens andre, heriblandt de ældre medlemmer af gruppen, var blevet „overtaget", nogle tilmed mere end en gang.

Under et møde i gruppen diskuterede man, hvorvidt det var godt eller dårligt at vælge leviratet fra. Diskussionen foregik på det lokale sprog, og min assistent var snart så opslugt af diskussionen (hun var selv enke, der havde fravalgt levirat), at hun helt glemte at oversætte. Jeg forstod dog, at gruppen var delt i to i spørgsmålet om det forsvarlige $i$ at vælge leviratet fra. Det sociale ansvar kunne man ikke frasige sig, men spørgsmålet var, om man ved at vælge fra var moralsk uansvarlig eller ikke. Den ene lejr anklagede den anden for at være skyld i, at chira var så udbredt, mens den anden lejr anklagede den første for at være konservativ i sin fastholden af traditionen. Tydeligt inspireret af et mere modernistisk kvindebillede end de ældre kvinder i gruppen mente min assistent efter seancen, da vi cyklede hjem, at det hele handler om retten til at bestemme over sin egen krop.

Det fremgik tydeligt af mødet, på trods af mine manglende sprogkundskaber, at der var tale om en forhandling af den status, kvinder som Frida har i samfundet. Fridas 
valg legitimeres i gruppen, ved at hun på et moralsk og etisk niveau får støtte af nogle af de øvrige medlemmer, mens andre benytter begivenheden til at henlede opmærksomheden på det socialt uansvarlige $\mathrm{i}$ at nægte levirat og til at hævde, at enkerne $\mathrm{i}$ chodo kola var skyld i chira. Dette argument høres ofte, når der sker en ulykke, som for eksempel da en syvårig pige blev bidt af en slange i klasseværelset på skolen i nærheden af Fridas hjem. Historien fortæller om slangen der kom tværs over skolegården, hvor læreren så den. Da den havde kurs mod klasseværelsets dør, opfordrede han alle eleverne til at krybe ud ad vinduerne. Den pågældende pige adlød ikke, men krøb hen over to bænke og faldt over den sidste foran døren, netop som slangen var krøbet ind i klassen. Den bed hende i skulderen, og hun døde kort efter. I samtaler om episoden diskuterede man årsagen til ulykken, og som Susan Whyte (1997) har beskrevet det for bunyolefolket i Uganda, så præger usikkerhed og tvivl processen, når noget sker, når for eksempel et barn dør, såvel som det præger processen i fortolkningen af det skete. Hekseri og chira er led i denne proces, og i den pågældende historie var netop enkerne, der nægter levirat, måske skyldige, for deres handling - eller mangel på handlen, skal man vel snarere sige - forårsager chira, der får den slags ulykker til at ske.

Det er hovedsagelig de yngre kvinder, der er på Fridas side, mens de ældre i langt højere grad syntes at forsvare traditionerne. Dette kan opfattes som et udtryk for en udfordring af de hierarkier, der præger det patrilineære samfund, gerontokratiet. Aldershierarkiet er ellers ofte beskrevet som stærkt fremherskende i luo-samfundet, for eksempel må især unge mødre ukritisk følge deres svigermors råd, når børnene er syge. Ringsted (2000) beskriver for eksempel, hvordan en mor i hemmelighed må snige sig ud af dalaen for at komme til klinikken med sit syge barn.

Kategoriseringen af kwer er situationel, men at nægte levirat er altid kwer, og den slags kwer forårsager chira, der rammer ikke blot enkens egen familie, men tillige falder tilbage på samfundet som helhed. Derfor er det på ingen måde et privat anliggende, hvordan man håndterer sin urenhed som enke. Enkegruppen, som Frida er medlem af, er med til at forhandle moralske aspekter af modernitet ved at tage fat på levirat-problematikken i samfundet. Gruppens debat afspejler forskellige moralske horisonter, og når man ser på kvindegrupperne mere generelt, er disse fællesskaber et modernitetens gode, som giver kvinderne rum for ikke alene at hjælpe hinanden økonomisk, men også moralsk.

Frida var ofte ikke i stand til at bidrage til pengeudvekslingen og mødte så ikke op i gruppen. I sådanne tilfælde ville min assistent eller andre medlemmer gå forbi hendes hus for at se, om hun var o.k., og om de kunne hjælpe hende. Man ville måske tage lidt majs eller sukker med til hende - eller tilkalde antropologen for økonomisk bistand til medicin til et sygt barn for eksempel Min assistents hjælp til Frida havde været at indrullere hende i mit studie. ${ }^{5}$ Derved sikrede hun Frida for en tid; antropologens medfølelse sikrede et vist niveau af individuel udviklingsbistand!

Fridas ikke-slægtskabsbaserede relationer i enkegruppen var støttende på en måde, som jeg først antog erstattede hendes tabte slægtskabsbaserede relationer. Jeg indså dog, at de to forhold ikke kunne forstås adskilt fra hinanden. Fridas forhandling i familien var snarere betinget af, at hun fik moralsk støtte i gruppen, og hendes status i gruppen var knyttet til hendes fravalg af levirat, som havde ført hende ud i den situation, hun nu var i.

Debatten i enkegruppen viste, at der var meget på spil for både enkerne selv og andre. Mange opfatter enkernes fravalg af levirat-ægteskab som selve årsagen til den 
megen chira, som man mener præger samfundet - hvor man i et vestligt, medicinsk perspektiv kan hævde, at levirat-ægteskabet, som det konstrueres i dag, er en væsentlig faktor i spredningen af hiv/aids. Symptomer på chira og aids er for så vidt identiske.

Moral kan ses som et aspekt af forbundethed såvel som et aspekt af slægtskab. Det kan ligestilles med Hutchinsons konkrete substans, der skaber samhørighed. Slægtskab bliver, i forhandlingen om mad i relation til de til slægtskab og traditioner knyttede forpligtelser, et aktiv, som vi vil se. Lad mig således uddybe Fridas situation i relation til slægtskab, primært ved at se på mad som en substans af forbundethed, der er ligestillet med moral.

\section{Mad og slægtskab}

Frida er i sit hus på stranden, sammenlignet med kvinder, der bor i et udvidet hushold $i$ en dala, temmelig alene om at klare dagligdagen. Hun har ikke jord til at dyrke grøntsager på, men er også for syg til at gøre jorden klar til at plante i. Dette foregår ved håndkraft, kun de færreste har råd til at leje okser til pløjning. Jorden ved søen er frugtbar, men flodheste æder ofte afgrøderne om natten, så omkring søen er den mest almindelige levevej at opkøbe fisk, når de landes, og så gå til markedet nogle kilometer borte for at sælge der med en mindre profit til følge. Frida orker ikke gåturen. Hun er således temmelig afhængig af andres hjælp, hendes egen indsats begrænser sig til at samle lidt „traditionelle“ grøntsager, dvs. vildtvoksende blade og rødder, i bushen. På trods af sin håbløse situation fortæller hun, at der ikke er støtte at få, når hun henvender sig til sine svogre. Det faktum, at brødrene har lejet huset på stranden, er ikke et udtryk for, at de påtager sig levirat, selv om det er et led i dette at sørge for et hus til enken, hvilket jeg vender tilbage til. Fridas svigermor gav dog ofte Fridas børn mad, hvilket forklarede, at de så relativt velnærede ud, i modsætning til Frida selv, der var grå i ansigtet og meget tynd. Hun fortalte, at hun var blevet behandlet for tuberkulose, men at behandlingen ikke virkede, fordi hun ikke fik nok at spise. ${ }^{6}$ Frida selv kom, i modsætning til børnene, aldrig i dalaen og hævdede, at svigermoderen ikke gav hende mad. Men selv om Frida i begyndelsen hævdede, at svigermoderen ikke gav hende mad, oplevede jeg flere gange, når jeg spurgte til det konkrete indhold i gryden under mine hyppige besøg hos Frida, at hun havde fået en portion bønner og majs eller andet fra sin svigermor. Grunden til denne uoverensstemmelse mellem, hvad Frida fortalt, og hvad der reelt skete, var en gåde, men udsigten til, at min empatiske forståelse af hendes elendighed ville føre til betydelige økonomiske bidrag, spillede nok en rolle.

\section{Klan og familie}

For at forstå situationen i Fridas familie er det nødvendigt at skelne mellem det, vi kunne kalde familien og klanen. ${ }^{7}$ Klanen er slægtens reproducerende enhed, hvilket $\mathrm{i}$ forståelsen her omfatter både slægten og den reproduktion, der forbinder slægtsled og sikrer klanens beståen, altså slægt plus skabelse eller tilblivelse. I klanen er det, der er på spil, altså slægtens overlevelse og videreførelse, både fysisk og moralsk, og aktørerne i klanen er, som i traditionel slægtskabsanalyse, mænd. Frida som enke, såvel som 
hendes døtre, er ikke umiddelbart interessant $\mathrm{i}$ klansammenhæng når hun ikke vil acceptere levirat. Men hendes valg udgør en trussel mod klanens overlevelse. Argumentet her afspejler for så vidt Derrick Stennings (1971) begreb viability, social bæredygtighed. Han har diskuteret begrebet i relation til fulani-hushold og redegør blandt andet for, hvordan viablility på husholdsniveau er afhængig af en balance mellem ressourcer og behov, en balance, der ændrer sig løbende i familiens livscyklus. Han beskriver, hvordan fulani-mænd og -kvinder, efterhånden som de bliver gamle, og deres børn bliver voksne og selv får børn, mister betydning for klanens viability. På samme måde kan man sige, at Frida har mistet sin betydning for klanens og husholdets viability, og derfor er eksklusionen blevet en realitet, materialiseret ved huset på stranden.

Jeg vil nu se nærmere på det, jeg kalder familien. Det er ikke det, Stenning beskæftiger sig med, idet hans tilgang er mere strukturalistisk, men jeg vil alligevel medtænke hans begreb i relation til familien og den sociale reproduktion på det, vi kunne kalde hverdagsniveau. Jeg vil minde om, at min skelnen mellem klan og familie er en analytisk skelnen, og at dalaen rummer begge aspekter.

Fysisk består dalaen af et antal huse, som er systematisk placeret i henhold til aldershierarki samt ægteskabelig status. Lige frem for indgangen til gårdspladsen ligger den ældste førstehustrus hus, mens anden og eventuelt tredje hustru har huse til henholdsvis højre og venstre for førstehustruens hus. Der vil måske være andre, mindre huse, som er køkken og forrådshuse. Foran disse huse ligger de voksne sønners simba, et lille hus, som er deres hjem, indtil de får en hustru. I begyndelsen af ægteskabet vil et ungt par bo i dette hus, og hustruen vil ofte lave mad i svigermoderens køkken. Senere vil manden bygge sin hustru et hus, og senere igen vil parret måske grundlægge deres egen dala, oftest lige neden for forældrenes. Enkelte flytter naturligvis længere væk, men selv de mænd, som tager til byen for at arbejde, vil have en simba hjemme i dalaen, og det forventes, at han bygger et hus til sin hustru i dalaen, selv om de bor i byen (for en interessant uddybning af dette, se Cohen \& Odhiambo 1992).

Strukturen i dalaen såvel som den måde, nye dalaer grundlægges på, afspejler slægtskabssystemet. Placeringen af husene samt husenes døråbning vender mod indgangen eller „nedad“, hvilket ifølge den lokale udlægning symboliserer kontinuiteten i slægten, det, at klanen lever videre (se Prince 2004 og Ocholla-Ayoyo 1976 for en uddybende beskrivelse af dette).

Når en kvinde er i chodo kola, som Frida, kan hendes afdøde mands brødre ikke bygge et hus til hende, når det gamle falder sammen, medmindre en af dem bliver hendes levir. De fleste huse er semipermanente, og bygningen af huse er en vigtig begivenhed, som materialiserer en kvindes tilhørsforhold til familien. Prince (2004) beskriver, hvordan det er almindeligt at håndhæve traditionerne i relation til husbyggeri, selv når man får håndværkere til at bygge huset. Manden graver hullet, hvorefter han sammen med sin hustru skal placere den centrale pæl, der holder hele huset. Hustruen skal ligeledes placere den første klump mudder til væggene. Når huset er færdigt, må manden tænde et bål inde i det. Hustruen tilbereder et måltid i køkkenhytten eller på et bål udenfor, og parret spiser dette sammen. Også et rituelt samleje finder sted i denne indvielse af huset, som skal gøre huset til et levende sted, hvor børn fødes, og slægten fortsættes. Hvis disse rituelle handlinger ikke udføres på den rigtige måde, kan en kvinde ikke bo i huset; det betragtes som et „dødt“ hus. Som Prince siger om huset: 
Det repræsenterer kvindens kropslige og sociale væren, en repræsentation, der i sig selv produceres gennem den ægteskabelige relation - relationen af komplementaritet imellem hustru og ægtemand. Det repræsenterer således kvinden, ikke som individ, men som hustru og mor (2004:163, min oversættelse).

Det var derfor for så vidt en fin løsning, ovenstående taget i betragtning, for Fridas svogre at leje et hus. Husene til udlejning lejes af kvinder i situationer, der ligner Fridas, eller af kvinder, der bruger huset til deres forretninger (se Obbo 1980 for en diskussion af enlige kvinders situation blandt henholdsvis buganda og luo).

Man kunne sige, at mændene fandt en innovativ måde at løse problemet med husbyggeri på, en måde, som lod Frida vælge traditionen fra, og som samtidig reducerede risikoen for chira, ved at hun fik et hus, uden at de byggede det for hende, og tilmed et hus, der lå uden for dalaen. For at vende tilbage til Stenning (1971) kan man sige, at de fandt en måde at genoprette klanens viability på, for hvilken chira jo må siges at være en trussel. Selv om slægtskabsbånd og de dertil knyttede forpligtelser er stærkt normative blandt luo, ser vi, at aktører har et aktivt forhold til dem. Slægtskabsstrukturen er en social organisation, som er normativ, men altså ikke statisk. Dette aktive forhold kan vi forstå ved først og fremmest at identificere reglerne for strukturen - helt i tråd med Evans-Pritchard (og Stenning for så vidt), om end fokus i hans strukturfunktionalisme var at identificere strukturen som en politisk organisation snarere end at se på, hvordan folk etablerer og forhandler den. Kun ved at kende det normative kan vi se forhandling, brud på regler og forandring i den måde, slægtskab organiserer samfundet på. På den måde bliver slægtskabssystemet, set $i$ et traditionelt perspektiv a la Evans-Pritchard $(1949,1950)$, ikke begrænsende for forståelsen af individers handlinger, men derimod et afsæt for at se, hvad der er på spil for kvinder og mænd i luo-verdenen, for at forstå deres handlerum.

Lad os nu, i lyset af Evans-Pritchard suppleret med en mere kvindecentreret tilgang a la Obbo (1980), se på forholdet mellem kvinder og mænd i familien. Er kvinder som Frida fuldstændig underlagt mænds beslutninger? Hvor rigid er strukturen? Med andre ord, hvordan forhandler kvinder som Frida deres position i familien? Obbo beskriver, hvordan især kvinder i byen i Kenya og i Uganda finder alternative måder at overleve på, hvordan de gør sig uafhængige af familien og i stedet knytter sig til naboer og ligesindede. Også Ogden (1996) beskriver, hvordan kvinder lever et liv uden for mænds kontrol og forhandler moralske aspekter af livet op imod en anden målestok end den til slægtskab og en mandsdomineret verden knyttet moralsk diskurs. Men kan Frida forhandle sin position som ekskluderet af familien? Boligproblemet løstes på en måde, der lod klanen opretholde sin viabilitet, sin sociale bæredygtighed, en løsning, der således var i klanens interesse mere end i Fridas favør. På den måde materialiserer huset på stranden Fridas eksklusion fra det fællesskab, der skulle være hendes sociale netværk. Men var Frida så fuldstændigt afskåret fra familien? I hvilket omfang gjaldt eksklusionen? Og gjaldt eksklusionen også Fridas børn? Børn hører til i den patrilineale familie, og mødre, der for eksempel ønsker skilsmisse, må ifølge traditionen efterlade deres børn hos deres far.

Mens mænd synes at herske over slægtskabet og definerede Fridas status i det, vi har kaldt klanen synes kvinder at have en anden tilgang til slægtskab, en tilgang, som er mere fokuseret på relationer, der for så vidt afspejler andre relationer mellem kvinder 
i samfundet. Jeg har kort nævnt, at Frida og hendes børn også fik mad af svigermoderen. Dette kan ses som et oprør mod mændenes beslutning eller som et udtryk for, at relationer er dynamiske og situationsbestemte og præget af uforudsigelighed. Jeg vil ikke argumentere for, at det er en kønsbestemt forskel, at mænd er mere strukturerede end kvinder. Mændenes løsning af Frida som et problem for klanen illustrerer, at også de er dynamiske og finder situationsbestemte løsninger. Jeg vil blot hævde, at der er mere på spil end slægtskabsstruktur og social organisation, og at et mere aktørorienteret perspektiv viser os, hvordan strukturen er et afsæt for folks handlinger, et afsæt, der i varierende grad begrænser deres handlerum, men som ikke er statisk.

Selv om kvinder er underlagt mænd i den patrilineale samfundsorganisation, der præger hverdagen, så er mad et kvindeligt anliggende. En farmor kan for så vidt inkludere sine børnebørn og i princippet også Frida i familien, selv om de er ekskluderet af klanen, fordi hun har magten over tildelingen af mad. Holtzman beskriver en lignende forhandling af magtrelationer blandt kenyanske samburu (2002). Ved at anvende Appadurais koncept ,gastropolitics“, som indfanger ,the everyday domestic politics of the allocation“" (Appadurai i Holzman 2002), viser Holzman, hvordan kvinders magtrelationer i det perspektiv ser helt anderledes ud end i et patrilinealt og gerontokratisk perspektiv. „Gastropolitics"8 lader os se, hvordan kønshierarkiet er til forhandling i forhold til tildeling af mad. Fridas svigermor kan ved at give mad til børnene og Frida skabe en relation til familien, selv om de er ekskluderet fra klanen.

Mad og økonomiske ressourcer i bredere forstand er vigtige i forhold til etableringen af relationer, både slægtskabsrelationer og anden forbundethed. Tildelingen af mad og andre ressourcer integrerer og disintegrerer i en verden, hvor sult og fattigdom er hverdagens betingelser. Fridas bosættelse uden for dala disintegrerer hende i forhold til klanen, mens svigermoderens sporadiske input i Fridas gryde etablerer en relation til familien. Fridas angivelse af, at svigermoderen ikke gav hende mad, som var i modstrid med, at indholdet i gryden ofte kom fra svigermoderen, afspejlede antageligt en forhandling af Fridas status i familien. Hun havde ikke ret til mad eller andre ressourcer i sin position som ekskluderet, en ret, som slægtskabsforpligtelser ellers skulle sikre. Men hun og svigermoderen fandt en måde at forhandle situationen på, som ikke nødvendigvis udfordrer mandshierarkiet, der er indbygget i det patrilineale system, i hvert fald så længe vi opretholder vor analytiske skelnen mellem familie og klan. Holzman ophæver med Appadurais begreb gastropolitics denne skelnen og lader os se på forhandlingen om mad som et tavst snarere end et åbent oprør mod mændenes beslutning om eksklusion (Holzman 2002). Hvorvidt der er tale om et sådan oprør, er ikke interessant her, hvor jeg fokuserer på Frida. For hende er det relationen til svigermoderen, der er vigtig, fordi den betyder mad i gryden, og sådanne relationer er livsvigtige i hendes situation. Hendes eneste mulighed er altså at forhandle sin position i relation til gastropolitics. Det er her, at man kan tale om slægtskab som et aktiv. Forholdet mellem bedsteforældre og deres børnebørn i det vestlige Kenya er emnet for Geissler og Prince i en artikel fra 2004. De hævder, at kærlighed er vigtig i denne sammenhæng. Børns behov er socialt konstruerede som kvindelige, domestiske anliggender, og mad er kærlighed. Commensality, fællesskab, er den substantielle basis for forbundethed (op.cit.:103). Begrebet commensality er diskuteret i en artikel af Mayer (1996), med Indien som det empiriske grundlag, og han viser, hvordan commensality ikke blot er fællesskab, men en fælleshed, der rummer forskelle i rang, så at sige. Bedstemødre er i et andet livsstadie end mødre. Som hustru og 
mor er kvinden centrum for produktion og reproduktion og har kun begrænset autoritet. Efterhånden som hun bevæger sig ud af den reproduktive rolle, vokser hendes personlige frihed såvel som hendes autoritet. Rollen som bedstemor er generelt værdsat, hvilket underbygger hendes autoritet og definerer hendes rang. I relation til Frida er hendes dani, børnenes bedstemor, i stand til at tildele Frida mad, ifølge ideen om gastropolitics, men hun har også kapacitet til at inkludere børnene i familien. Frida forhandler således sine børns relation til familien og til klanen ved at bruge slægtskab som et aktiv. Det at dele mad skaber commensality, og især slægtninge er forpligtet til at dele selv den mindste smule, man har (Geissler \& Prince:108). Når jeg talte med Frida om, at hun kunne dø af sin sygdom, undrede det mig, at hun ikke syntes bekymret for sine børns fremtid. Ved at se slægtskab som et aktiv, som Frida anvendte i sin forhandling af sine børns rettigheder, og ved at se, hvordan mad, modernitet og moral udgør aspekter af slægtskab og forbundethed i Fridas verden, rejser der sig en aktør ud af en position, som ikke umiddelbart syntes at rumme handlingsmuligheder.

Fridas eksklusion var som sådan ikke absolut. Ved at forhandle sin position i samfundet fandt hun styrke til også at forhandle sin situation i sin familie. Dette blev understreget den sidste gang, jeg mødte Frida. Hun var indlagt på klinikken til behandling, betalt af hendes svogre. De havde dog kun indvilget $\mathrm{i}$ at betale for fire dages behandling, og da disse snart var forbi, og hun stadig havde behov for behandling, fandt vi i fællesskab frem til, at tiden var inde for hende til at finde vejen til en ngo i lokalområdet, som hjælper enker, der er hiv-positive.

\section{Konklusion}

Gennem en aktørbaseret analyse af, hvordan udvekslinger i kvindegrupper konstituerer ikke-slægtskabsbetingede fællesskaber, kunne jeg hævde, at modernitetens indflydelse på kvinders liv i det vestlige Kenya åbner nye rum for kvinders innovative forhandling af forandring og udvikling, en virkelighed, som ville finde plads i nyere slægtskabsteoretiske rammer, analyser af forbundethed. Jeg har imidlertid vist, hvordan både aktør perspektivet $o g$ en mere strukturel slægtskabsanalyse er relevant for forståelsen af Fridas situation såvel som for andre kvinder og mænd i det vestlige Kenya. Slægtskabssystemet har stor betydning for folk og deres handlinger, handlinger, der både vedligeholder, udfordrer og forhandler slægtskabsbaserede sociale organisationer og hierarkier. På den måde afspejler min pointe Janet Carsten (2000, 2004), som argumenterer for, at folk er bevidste om deres relationer, og for, at forbundethed konstant konstrueres i hverdagens handlinger. Mad, penge og andre ressourcer har en status, der kan ligestilles med blod, hævder Hutchinson på baggrund af sit arbejde blandt nuerfolket i Sudan. Jeg hævder altså, at vi kan se moral i samme perspektiv, og som et led i de moralske horisonter, som kvinder som Frida orienterer sig imod, må vi inddrage slægtskabsstrukturer som et bærende element af kulturen, helt som en strukturfunktionalist som Evans-Pritchard ville gøre det. Vi skal således ikke erstatte gamle pengesedler med nye, men vedblivende være opmærksom på også de gamles værdi.

Kvinder var ikke synlige som handlende, tænkende væsener i de klassiske strukturanalytiske beskrivelser af parallel- og krydskusineægteskaber. Heller ikke som modstillet både manden og kvæget i sit moderskab, som Stenning beskriver det, fik kvinden nogen 
stemme eller agens. Jeg vil naturligvis ikke agitere for en tilgang, der kun ser på halvdelen af samfundet - mænd - og kun på et specifikt niveau - social organisation. Jeg har gennem min analyse af empiri fra det vestlige Kenya vist, at det er vigtigt at se på de praksisser, der reproducerer eller forandrer de selv samme strukturer, som præger praksis, frem for at antage, at strukturen determinerer praksis på en simpel måde. En aktørorienteret tilgang må forudsætte en forståelse af agens som den ,sociokulturelt medierede kapacitet til at handle“" (Ahearn 2001:112, min oversættelse og fremhævelse). Frida og alle de andre kvinder, mænd og børn i det vestlige Kenya såvel som andre steder, handler situeret - de handler ud fra specifikke sociale og kulturelle forudsætninger som ikke er statiske, men specifikke for tid og sted.

\section{Noter}

1. Artiklen er baseret på i alt fire måneders feltarbejde i Kenya som led i min kandidatuddannelse på Institut for Antropologi, Københavns Universitet. Feltarbejdet såvel som efterfølgende specialeskrivning var faciliteret af DBL Institute for Health Research and Development. Feltarbejdet var finansieret af henholdsvis RUF/ENRECA-midler, Nord \& Syd - Center for Afrikastudier og NAIS, Uppsala. Til alle disse aktører skal rettes en dybfølt tak.

2. Artiklen her er dedikeret til Frida og alle de andre informanter, som ikke blot ukritisk accepterede antropologens ret til at spørge til hvad som helst. Frida var en af mine nøgleinformanter, som jeg besøgte mere end 10 gange. Nogle besøg var mere formelle interviews, mens andre havde karakter af ,høflighedsvisitter“.

3. Betegnelserne her - traditionel over for moderne som svarende til lokal over for vestlig - reflekterer den lokale anvendelse af begreberne.

4. Evans-Pritchard nævner også denne praksis omkring enker (1950).

5. Assistenten havde tidligere havde oplevet, at noget ,faldt af" til informanter i antropologiske feltarbejder, og var tydeligvis opmærksom på sit sociale ansvar, når hun foreslog informanter. I Fridas tilfælde lod det ydermere til, at hendes yngste barn faktisk var ældre, end de angav. Mine inklusionskriterier omfattede kravet om, at informanten skulle være mor til et barn under tre. På trods af disse betingelser - eller måske netop derfor - blev Frida en af mine vigtigste informanter.

6. Det forekommer rimeligt at antage, at Frida har aids. Jeg forsøgte at sende Frida til en ngo i området, som arbejder med at hjælpe aids-syge enker i netop den svære situation, som Frida befandt sig i. Men hun hævdede, at de ikke ville inkludere hende i projektet, så der var ingen hjælp for hende der. Projektet var baseret på et tilbud om en test. Hvis denne test var positiv, tilbød man økonomisk støtte i et vist omfang til for eksempel medicin. Der var dog ikke tale om behandling af aids, men af de infektioner, der præger livet med aids. Frida ønskede formodentlig ikke en test, og hun kunne i så fald ikke inkluderes i projektet. Det er en udbredt opfattelse, at kun en test kan afgøre, om en række symptomer skyldes aids eller chira. Symptomerne på chira er mange forskellige, blandt andet dem, man i biomedicin ville definere som symptomer på underernæring og infektioner, symptomer, der også er en del af billedet af aids. Chira bliver som omtalt betragtet som et meget alvorligt anliggende og kan medføre døden, akkurat som aids gør det. At få udført en test for hiv er ikke videre attraktivt, da diagnosen er stærkt stigmatiserende, og behandlingsmulighederne er på det nærmeste ikke-eksisterende. Mange har ikke tillid til, at prøvesvaret forbliver mellem den enkelte og klinikken. Så hvis spørgsmålet ikke ligefrem hænger i luften, er chira mere sandsynlig i den lokale forståelse, når folk lider af symptomer, der også kunne være tegn på aids.

7. Denne skelnen mellem klan og familie reflekterer for så vidt den klassiske opdeling, som Fortes (1958) kaldte „domestic“ og „political-juridical“.

8. „Gastropolitics“ er bibeholdt på engelsk sammen med definitionen af begrebet, da en oversættelse bliver for konstrueret og meningsforvirrende. 


\section{Litteratur}

Ahlberg, Beth Maine

1991 Women, Sexuality and the Hanging Social Order. The Impact of Government Policies on Reproductive Health in Kenya. Schweiz: Gordan and Breach.

Achola, Milcah Amelo

$1991 \quad$ Women in Siaya District: Objectives, Constraints and Achievements. I: Suda Were \& Olenja (eds.): Women and Development in Kenya. Siaya District. Nairobi: Institute for African Studies.

Ahearn, Laura M

$2001 \quad$ Language and Agency. Annual Review Anthropology 30:109-37

Carsten, Janet

2000 Introduction: Cultures of Relatedness. I: Janet Carsten (ed.): Cultures of Relatedness.

New Approaches to the Study of Kinship. Cambridge: Cambridge University Press.

2004 After Kinship. New York \& Cambridge: Cambridge University Press

Cohen, David William \& E.S. Atieno Odhiambo Odhiambo

$1992 \quad$ Burying SM. The Politics of Knowledge and The Sociology of Power in Africa. London:

James Currey.

1989 Siaya. The Historical Anthropology of an African Landscape. Nairobi: Heineman.

Evans- Pritchard, E.E

1949 Luo Tribes and Clans. Rhodes-Livingstone Journal 7:24-40

1950 Marriage Customs of Western Kenya. Africa 20(2):132-42

Geissler, Wenzel \& Ruth Prince

2004 Shared Lives: Exploring Practices of Amity between Grandmothers and Grandchildren in Western Kenya. Africa 74(1):95-120.

Holzman, J.

2002 Politics and Gastropolitics: Gender and the Power of Food in two African Pastoralist Societies. Journal of the Royal Anthropological Institute 8:259-78.

Hutchinson, Sharon E.

$2000 \quad$ Identity and Substance: The Broadening Bases of Relatedness among the Nuer of Southern Sudan. I: Janet Carsten (ed.): Cultures of Relatedness. New Approaches to the Study of Kinship. Cambridge: Cambridge University Press.

KDHS (Kenya Demografic and Health Survey)

1998 National Council for Population and Development. Macro International Inc

2003 Preliminary Report. Central Bureau of Statistics/ Ministry of Health. Nairobi.

Mayer, Adrian

1996 Caste in an Indian Village: Change and Continuity 1954-1996. I: C.J. Fuller (ed.): Caste Today. Delhi: Oxford University.

Meinert, Lotte

2001 The Quest for a Good Life. Health and Education among Children in Eastern Uganda

Ph.d.-rækken nr. 19. Institut for Antropologi, Københavns Universitet, og Danish Bilharziasis Laboratory.

Mogensen, Hanne

1999 Mothers'Agency - Others Responsibility: Striving for Childrens' Health in Eastern Uganda.

Ph.d.-rækken nr. 13. Institut for Antropologi, Københavns Universitet.

Obbo, Christina

$1980 \quad$ African Women. London: Zed Press

Ogden, Jessica

1996 'Producing' Respect: The 'Proper Woman' in Post-Colonial Kampala. I: R. Werber \& T.

Ranger (eds.): Post Colonial Identities in Africa. London: Zed Books. 
Ocholla-Ayoyo, A.B.C

1976 Traditional Ideology and Ethics among the Southern Luo. Uppsala: Scandinavian Institute of African Studies.

Pala, Achola

Daughters of Lakes and Rivers: Colonization and Land Rights of Women. I: M. Etienne \& E. Leacock (eds.): Women and Colonization in Anthropological Perspectives. New York:

Praeger/ Bargin Publ.

Prince, Ruth

2005 Struggling for Growth in a Time of Loss. Challenges of Relatedness in Western Kenya. Ph.d. rækken nr. 32. Institut for Antropologi, Københavns Universitet, og DBL - Institute of Health Research and Development.

Potash, Betty 1986

Widows in Africa: An Introduction. + Wives of the Grave. I: B. Potash: Widows in African Societies: Choices and Constraints. Stanford: Stanford University Press.

Ringsted, Mette

2000 Den gode mor løber ... En analyse af handlekraft, børneomsorg og luo-mødres selvforståelse i det vestlige Kenya. Specialerækken nr. 166. Institut for Antropologi, Københavns Universitet.

Stenning, Derrick J.:

1971 Household Viability among the Pastoral Fulani. I: Jack Goody (ed.): The Developmental

Cycle in Domestic Groups. Cambridge: Cambridge University Press.

Teglhus, Lene

2005 Passages to Motherhood: Struggling Along in a World of Uncertainty. Specialerækken nr. 365. Institut for Antropologi, Københavns Universitet.

Were, Gideon et al.

1991 Women and Development in Kenya, Siaya District. Nairobi: Institute of African Studies.

Whyte, Susan

1997 Questioning Misfortune. Cambridge: Cambridge University Press. 